Amsterdam: International Association for the Evaluation of Educational Achievement.

Tsang, W. K. (1998). Patronage, domestication or empowerment?: Citizenship development and citizenship education in Hong Kong. In O. Ichilov (Eds.), Citizenship and citizenship education in a changing world (pp.221-253). London: Woburn.

Tse, K.C. (1997). The poverty of political education in Hong Kong secondary schools. Hong Kong: Hong Kong Institute of Asia-Pacific Studies, The Chinese University of Hong Kong.

Tse, K.C. (1998/1999). Civic education in four Chinese societies: Chinese mainland, Taiwan, Hong Kong and Macau. Education Journal, 26 (2) and 27 (1), 179-200 (In Chinese).

Wei, T. T. (1994). Moral education in Singapore: A critical appraisal. Journal of Moral Education, 23(1), 61-73.

Wong, K.Y. (1996). The ethnic and national identities of the Hong Kong people: A liberal explanation. Issues and Studies, 32, (8), 105-130.

Wong, K.Y., \& Shum, K.C. (1996). The national awareness of Hong Kong youth. Hong Kong: Hong Kong Institute of Asia and pacific Studies, Chinese University of Hong Kong.

Xu, Z. (1996, August 9). Reflection on the flawed arguments of national education. Mingpao (in Chinese).

Yahuda, M. (2000). The changing faces of Chinese nationalism. In M. Leifer (Eds.), Asian nationalism, (pp. 21-37). London: Routledge.

Zhao, S. (2000). Chinese nationalism and authoritarianism in the 1990s. In S. Zhao (Eds.), China and democracy: Reconsidering the prospects for a democratic China (pp. 253-270). New York: Routledge.

\section{Notes}

1. There are six so- called 'pro-China' secondary schools in Hong Kong. They had a very long history of following closely the policy of People's Republic of China, even in the era of the British colonial government. The school hoisted the national flag and celebrated the National Day of the People Republic of China from the very beginning, even when Hong Kong was under British colonial rule. This was extremely uncommon under the colonial rule. They usually had very strong political educational leanings, especially in the 1960 and 1970. It was because of their loyalty to the People Republic of China, they were politically discriminated against and economically censored by the British colonialists. As a result, starting from the establishment of the schools till the 1980s, these pro-China schools were private schools and did not get any subsidies from the Hong Kong colonial government. Basically the schools were excluded from the main stream educational system of Hong Kong in that period of time.

In 1980, after the death of Chairman Mao, in particular, after the signing of the Sino-British Joint Declaration in 1984, which designated the sovereignty of Hong Kong to be returned to the People's Republic of China in 1997, the 'pro-China' schools began to return to the main stream educational system of Hong Kong. They changed from the status of private school to Direct Subsided School and obtained funding from the British colonial government. But they still held up to their very strong tradition of patriotism.

2. Number for analysis of data.

Received May 18, 2002

Revision received November 20, 2002

Accepted December 7, 2002

\title{
Correction Notice
}

In 2002, Vol. 3, No.1, of Asia Pacific Education Review, we notice unnecessary phrase was inserted in article written by MinHo Yeom, Clementina Acedo, and Erry Utomo. In the line 7 in the abstract section of page 56, "The main difficulties in implementing the policies, in the case of curriculum decentralization, were" should be omitted. 